\title{
Cultural heritage tourism research: a sustainable community-based design project for the San Antonio Mission Historic District
}

\author{
S. Doganer \\ College of Architecture, The University of Texas at San Antonio, USA
}

\begin{abstract}
This paper discusses how to provide maximum efficiency in the economical, historical, social, and cultural dimensions of tourism with sustainable development practices in order to support heritage tourism of the San Antonio Missions and development in South San Antonio.

The Missions of San Antonio are on the US "tentative list" to be advanced as possible UNESCO World Heritage Sites. The area designated as the Mission Historic District, located along the San Antonio River in the south section of the city, originally attracted both prehistoric Indian and historic Spanish and Anglo populations because of the prevalence of unique natural resources. The historic San Antonio River has long served as the heart of the city. Each year the worldrenowned River Walk draws millions of visitors, yet miles of urban river with untapped potential lie beyond downtown and the famed Paseo del Rio. A comprehensive, multi-year project is underway to restore and enhance 13 miles of the San Antonio River both north and south of downtown. A multi-phase project to develop the full potential of the San Antonio River is focusing on improving two sections of the river -Museum and Mission Reaches- that pose different challenges. The Mission Reach segment overlays with the research area of this paper, and provides a strong connection between the area and downtown. Mission Portals will connect San Antonio’s four historic missions - Mission Concepcion, Mission San Jose, Mission San Juan and Mission Espada - to the San Antonio River.

This research investigates and analyzes the potential of the San Antonio Mission Historic District towards community-based cultural heritage tourism. The connections of Missions to the river will feature historic and artistic interpretations of the story of the missions and highlight their social and cultural
\end{abstract}


importance to the area. This will reinforce the importance of the river to the missions and encourage visitors to circulate between the Mission Reach and the river. Accelerating tourism in Mission Historic District will be a considerable economic and social benefit through the workforce, income and infrastructure developments. This research provides a legacy of positive development within the Mission Historic District, especially as the San Antonio moves towards World Heritage designation. This paper will also promote cultural and environmental sustainability at the local or neighborhood level while giving tourists an option to experience the cultural heritage of the region.

Keywords: cultural heritage tourism, sustainability, community-based design.

\section{Introduction}

Tourism is one of the world's fastest-growing industry and business. International tourist arrivals grew by over $4 \%$ in 2011 to 980 million, according to the latest UNWTO World Tourism Barometer. The Americas (+4\%) saw an increase of 6 million arrivals, reaching 156 million in total. North America, with a 3\% increase, hit the 100 million tourists mark in 2011 [1]. According to the Economic Impact of San Antonio's Hospitality Industry report, from 1998 to 2008, the economic impact of the hospitality industry increased by more than 70\%. In San Antonio alone, hospitality industry employs more than 113,000 workers who annually generate $\$ 12.2$ billion dollars back into the local economy; making tourism one of San Antonio's largest industries [2].

San Antonio is one of the State's top tourist cities. The city has a rich and unique historic urban landscape characterized by its river with its famous 'Riverwalk', historic neighborhoods and major landmarks such as San Antonio Franciscan Missions which are on the US "tentative list" as possible UNESCO World Heritage Sites. It is expected that the river improvement project will also reinforce the connection to the San Antonio Missions, and encourage visitors to circulate along the river beyond the downtown area.

This research investigates and analyzes the potential of the San Antonio Mission Historic District towards community-based cultural heritage tourism. Accelerating tourism in San Antonio Missions Historic District brings considerable economic and social benefit through workforce, income and infrastructure developments. This paper proposes a project to support and connect community small business owners to the existing heritage tourism economy, and assist them in renovating and reusing their existing structures and properties. The purpose of the study is to foster prosperity for residents of the district. This in turn, will sustain the community's cultural heritage. Proposed project will capitalize on the existing plans for improvements of the San Antonio River and is timely as the current consideration for World Heritage designation of the San Antonio Missions will bring international attention to the district. 


\section{Cultural heritage tourism in the San Antonio Mission Historic District}

Cultural heritage tourism is "traveling to experience the places and activities that authentically represent the stories and people of the past and present” [3]. It is an economic development tool designed to attract visitors to an area based on the unique aspects of the locality's history, landscape and culture. This not only boosts regional and local pride but is also a good source of revenue for a community and creates jobs. Historic preservation is a tool for preserving a historic place, incubating small businesses, revitalizing downtowns, generating local jobs, and creating improvements in a community. It is estimated by World Tourism organization UNWTO in 2006 that between 35 and 40 percent of tourism today represents cultural tourism or heritage tourism. Lyon and Wells [4] states "As an alternative to mass tourism, cultural and heritage tourism offer opportunities for place-based engagement that frames contexts for interaction with the "lived space" and "everyday life" [5] of other peoples as well as sites and objects of global historical significance.”

San Antonio Missions play an important role in defining the city's culture. In 2009, over 1.7 million people visited Missions Concepción, San José, San Juan, and Espada while 26 million people visiting the city San Antonio in total. Collectively, these missions and associated features - including acequias (irrigation canals), labores (farm lands), dam and aqueduct, and the single remaining rancho (mission ranch) - comprise the San Antonio Missions National Historical Park [2].

San Antonio River was the lifeblood of the missions located within easy reach of its banks. San Antonio River Improvements Project (SARIP) will also affect the park by restoring the river's natural features, re-creating and preserving the natural ecosystem for the enjoyment of the area's residents and visitors. It is expected that the river improvement project will reinforce the connection to the San Antonio Missions, and encourage tourists to circulate along the river beyond the downtown area [2].

\subsection{San Antonio Mission Historic District}

The Catholic Church and the Spanish government established five mission compounds and a small military base in the 18th century that established today's San Antonio, Texas. These missions blended native traditions with newly adopted Spanish ways, and created a very unique culture. The communities still remain in the area is a very important part of San Antonio's rich cultural heritage [6].

San Antonio Mission Historic District, located along the San Antonio River in the south section of the city, includes the lower four missions (Listed from north to south: Concepcion, San Jose, San Juan Capistrano, and Espada), their acequias and fields. The area was originally attracted both prehistoric Indian and historic Spanish and Anglo populations because of the prevalence of unique natural resources. The abundant water, game, and other natural foods seem to have provided prehistoric Indians with an ample non-agricultural subsistence 
type of lifestyle based upon hunting, gathering, and fishing. The area was utilized for agricultural purposes as well as local industries after the establishment of the Spanish Missions [7].

The World Heritage Site (WHS) nomination is expected to be reviewed in 2015. Recognition as a World Heritage Site would put the missions in the company of fewer than 1,000 places around the world that are recognized for outstanding historical, artistic, scientific, or natural values [8]. WHS status can bring enhanced resources for conservation and additional funding and investment, and benefit nearby communities from increased visitation and tourist spending. These communities can also contribute to local economic development and revitalization. The new report on potential economic impact of WHS designation funded by Bexar community indicates that WHS designation could be both an outstanding promotional opportunity and a high-profile catalyst for developing more significant cultural and heritage tourism in the area [6].

\subsection{Demographics}

The San Antonio River South Area Coordinated Management Plan (2010) defines the demographic profile of the River South area as below:

"Between 1990 and 2008 the population within this area decreased slightly (-1\%) while San Antonio increased by 37\%. Residents within the corridor are $5 \%$ of the City's total population (approximately $66,000)$ and density averages 4.92 persons per acre. The median age is 32.7 years, slightly younger than San Antonio's average of 34 years. Almost $43 \%$ of the population 25 years and older, in this area has not completed a high school education... Educational attainment ties with income potential and discretionary spending. This area earns $\$ 30,630$, nearly $\$ 11,000$ less than the City average... Housing data shows that most residential structures account for $23 \%$ of the land use. They were built during the post WWII era and have a current median value of $\$ 54,843$ compared to the City of San Antonio average of $\$ 113,988$. Other major land uses in the area include parks 21\%, institutional 22\%, and commercial and vacant land both at $14 \%$." [9]

Analysis reveals numerous challenges to the area such as: declining population, lower educational levels, median income and higher poverty levels when compared to overall City data. Currently of great concern in the River South neighborhoods, is the crime rate. This alone has caused many neighborhood areas to rally and work for expanded team efforts with schools, churches, civic organizations and the City for revitalization to strengthen its viability and discourage criminal activity.

\subsection{Current planning studies and projects}

Current planning studies and investments around the Mission Historic District are San Antonio River Improvements Project/Mission Reach Ecosystem Restoration and Recreation, River South Area Coordinated Management Plan, South Central San Antonio Community Plan, Roosevelt Corridor Reinvestment Plan, and Citywide Design Guidelines for Historic Districts. 


\subsubsection{San Antonio River Improvements Project: Mission Reach ecosystem restoration and recreation}

Each year the world-renowned River Walk draws millions of visitors, yet miles of urban river with untapped potential lie beyond downtown and the famed Paseo del Rio. A comprehensive, multi-year project is underway to restore and enhance 13 miles of the San Antonio River both north and south of downtown. A multi-phase project to develop the full potential of the San Antonio River is focusing on improving two sections of the river -Museum and Mission Reachesthat pose different challenges. These enhancements are expected to have farreaching benefits for all of San Antonio, from increased economic development to cultural resources and recreational opportunities connecting neighborhoods. The Mission Reach segment provides a strong connection between the area and downtown. The Mission Reach Ecosystem Restoration and Recreation Project is transforming an 8 mile stretch of the San Antonio River into a quality riparian woodland ecosystem. As the Mission Reach project restores the natural ecosystem of the river, it will also reconnect the river to the historic Missions that relied on it hundreds of years ago. Mission Portals will connect San Antonio's four historic missions - Mission Concepcion, Mission San Jose, Mission San Juan and Mission Espada - to the San Antonio River. These connections will feature historic and artistic interpretations of the story of the missions and highlight their social and cultural importance to the area. This will reinforce the importance of the river to the missions and encourage visitors to circulate between the Mission Reach and the river. River Improvements Project planners are also working closely with the National Park Service San Antonio Missions National Historic Park to ensure that there is a seamless transition between the Mission Reach and the historic missions, and the proposed project helps to strengthen this transition [9].

\subsubsection{River South Area Coordinated Management Plan}

River South is an 8-mile stretch of the San Antonio River, adjacent neighborhoods and home to four of the San Antonio Missions. The investment of time, funding and improvements at both the street and River levels is key to this area realizing its full potential as an attractive, viable corridor. The project encourages economic diversity and job creation, which are compatible with San Antonio's natural and cultural resources; preserves and revitalizes existing housing through community heritage-based economic development and promotes targeted infill for new housing neighborhood improvements [9].

\subsubsection{South Central San Antonio Community Plan}

The South Central San Antonio Community Plan, adopted in 1999 and updated in 2003, covers the northern portion of River South to SW Military Drive. Plan elements cover neighborhood and community development, community facilities, transportation and quality of life. Emphasis is on infill development, housing stock and improving the quality of commercial corridors. A chief goal is to "enhance and improve the Missions, parks and the San Antonio River" through strategies aimed at zoning, safety, accessibility and restoration [9]. 


\subsubsection{Roosevelt Corridor Reinvestment Plan}

The Roosevelt Corridor Reinvestment Plan, adopted in 2009, includes four registered neighborhood associations in River South - Roosevelt Park, Riverside South, Mission San Jose and East Pyron/Symphony Lane. The goal for the Corridor is to encourage reinvestment in the Roosevelt corridor; Launch community-based initiatives to improve quality of life, Link existing business and property owners with funding sources, Create investment opportunities [9].

\subsubsection{Citywide Design guidelines for historic districts}

The Citywide Design guidelines provide to historic district residents, property owners, professionals working with historic properties, and potential construction applicants an understanding of architectural design principles and guidelines.

Besides these ongoing projects, National Park Services has also proposed and developed couple studies that would support the cultural heritage tourism activities and sustain the communities and the culture that the missions helped spawn. Some of these initiatives are "A Day in the Life of the Missions" handson cultural demonstration programming at Mission San José, a Spanish colonial demonstration farm on mission labores land at Mission San Juan, which will entail both new construction and new programming, and building a new park headquarters and research center, and restoring the landscape around Mission San José [2].

\section{A sustainable community-based design project for the San Antonio Missions District}

The concept for this project proposed is to engage Mission Historic District residents in small business development. The purpose of this project is to create prosperity for residents of San Antonio's Mission Historic District. It means to promote the continuity of heritage through the benefits which come from cultural heritage tourism. The project aims to provide technical preservation guidance and cultural heritage tourism knowledge to potential small business owners in reuse of existing, historic buildings and properties for new businesses. Prospective entrepreneurs will receive training and professional support to tap into the tourist economy that flows right past their front doors, and in turn, their efforts will support and sustain the cultural heritage of their community.

The proposal addresses the issues of cultural and environmental sustainability at the local or neighborhood level while giving tourists an option to experience the cultural heritage of the region. Studying the potential of the San Antonio Mission Historic District and encouraging sustainable cultural heritage tourism and related small-scale economic activities in the area will promote sustainable local economic development.

This project focuses on the potential of new business uses for existing buildings and properties in the Mission Historic District, while planning sustainable, opportunity rich, and economically competitive communities. Proposed project promotes cultural and environmental sustainability at the local 
or neighborhood level while giving tourists an option to experience the cultural heritage of the region.

This proposed project aims to provide individual property owners with a package of offerings. Highlights include:

- training workshops on Cultural Heritage Tourism including coverage of the financial aspects of Heritage Tourism;

- training workshops on historic preservation and re-use of existing buildings;

- business plans for small business owners, including marketing plans, social media, and information on area micro-lenders;

- community planning meetings and workshops;

- architectural design as well as workshops and services geared to revitalization efforts.

\subsection{Proposed geographic area}

In order to accommodate needs and expectations, this plan is scaleable and flexible. The project group will integrate with the ongoing efforts of other city agencies and with the community's interests to designate the locations best suited for implementation of the project. Targeting zones such as portals to the river and other key areas will be a vital component of the project.

\subsection{Method}

In order to create a plan with the greatest opportunity for success, the project group would engage with the local community to ensure that professional and scholarly collaboration is led by the community's vision for their own prosperity. The project includes three components which utilize public participation in every level of the project. Architecture and planning, tourism, and business groups will work together to develop a successful community-based cultural heritage tourism project in the Mission Historic District.

\subsection{Objectives}

This is a three year project. The objectives of the full life of the project are: to effectively communicate the values of heritage tourism; the conservation of cultural resources and the inclusion of community in decision-making.

The objectives for year one are to:

- $\quad$ identify the target area(s);

- determine the capacity, value and potential re-use of structures and properties within the proposed area;

- $\quad$ identify resident entrepreneurs for participation in the project;

- $\quad$ provide entrepreneurs with business tools for success.

The objective for year two is to take the project from planning to implementation. The project group will assist the selected participants by providing architectural design plans, and planned business and marketing strategies, in order to foster and nurture sustainable small business practices. 
The objective for the third and final year of this project is to implement all aspects of the project, including administration and monitoring of construction, business plans and outreach to tourists.

\subsection{Deliverables}

A summary of deliverables of the proposed three year project is shown in Table 1.

Table 1: $\quad$ Summary of deliverables of the project.

\begin{tabular}{|c|c|}
\hline 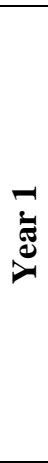 & $\begin{array}{l}\text { PROJECT REPORT } \\
\text { - Site Design Analysis } \\
\text { - Cultural Heritage Tourism Market Analysis } \\
\text { - Identification of the Project Target Area } \\
\text { - Architectural Inventory: An Assessment and Evaluation of } \\
\text { the Selected Properties in the Target Area } \\
\text { PROJECT INFORMATION WEB PAGE } \\
\text { EDUCATION AND TRAINING } \\
\text { - Community meetings on Cultural Heritage Tourism } \\
\text { - Business Plan Training } \\
\text { LIST OF POTENTIAL RESIDENT ENTREPRENEURS }\end{array}$ \\
\hline 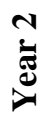 & $\begin{array}{l}\text { ARCHITECTURAL DRAWINGS } \\
\text { BUSINESS CONSULTANCY } \\
\text { COMMUNITY TRAINING SEMINARS }\end{array}$ \\
\hline 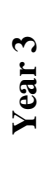 & $\begin{array}{l}\text { CONSULTANCY ON IMPLEMENTATION OF THE } \\
\text { PROJECTS } \\
\text { DESTINATION MARKETING STUDIES } \\
\text { FINAL REPORT }\end{array}$ \\
\hline
\end{tabular}

\section{Year one}

The deliverables for year one will include project report, project information web page, education and training opportunities, and list of potential resident entrepreneurs.

\section{Project report}

The project group will compile a comprehensive report that includes the sections detailed below. Each section will also be submitted for review as work is being completed. The project report will include a brief narrative of the historic context of the district and findings from previous analyses. The report will include photographs and maps, site design analysis, cultural heritage tourism market analysis, identification of the project target area, and architectural inventory. 
- Site design analysis This will be the first step in identifying the potential for heritage tourism businesses in the Mission Historic District as well as determining the area(s) best suited for the project. It will consist of two elements:

a. Review of previous planning studies: the proposal aims to build on the comprehensive regional plans for the Mission Historic District in order to augment the community vision. An analysis of existing documents will aid in identifying the locations best suited to the project. The documents for this analysis include, but are not limited to: the "Roosevelt Corridor Reinvestment Plan,” the San Antonio River Improvements Project's "Mission Reach Ecosystem Restoration and Recreation Project," the "River South Area Coordinated Management Plan," and the "South Central San Antonio Community Plan.” Guidelines issued by the City of San Antonio Office of Historic Preservation and recommendations from the San Antonio City Design Center will be included in the analysis.

b. Field survey and research around the missions (concentrated radius around the missions and mission portals within the Mission Historic District): the architecture and planning group will conduct a field survey of the area surrounding the missions in order to gather visual data on existing structures and properties. Observations from the field survey and analysis of GIS maps will provide information on qualities such as authenticity, historic significance, unique features, existing conditions, site infrastructure, and cultural heritage tourism potentials. The survey will include photographs and generated GIS maps.

- Cultural heritage tourism market analysis Concurrent with the site design analysis, the tourism group will conduct a market analysis to determine the nature of current cultural heritage activity and potential future activity.

The analysis will have two components:

a. A survey of visitors to the missions: a visitor survey will be conducted of visitors to the missions (excluding the Alamo) to determine a visitor profile and obtain visitor perceptions of the tourism facilities and services. Visitor surveys will be performed at the four missions and other high volume areas within the heritage district. Information gathered from the visitor survey will be used to provide recommendations for promoting tourism for the Mission Historic District.

b. Focus group(s): a focus group of 10 to 12 people, including managers of the historic mission sites, local community leaders, and managers of other tourism operations in the district will be held to gain a better understanding of their strategies, perceptions of heritage tourism, and the current status of research efforts regarding tourists. If necessary, a second group will be held to accommodate all interested parties.

- Identification of the project's target area(s) The project group will identify the target area(s) for the proposed project in collaboration with city and county officials and community residents. Identification of the area will be determined 
using information gathered from the field survey and meetings with community residents.

- Architectural inventory Upon determination of the target area, the architecture and planning group will prepare an architectural inventory of selected (up to 25) properties in the target area. The inventory will include: address, estimated date of construction, property type, historic significance, unique features, size, structural and nonstructural systems and materials, existing conditions, site infrastructure, and architectural and historical integrity of the surveyed properties. This inventory will be used to assess and evaluate the potential re-use of the properties.

\section{Project information web page}

Project progress as well as the final report will be made available on a project website, for better community awareness. Limited quantities of printed editions of the report will also be made available for those without Internet access.

\section{Education and training}

- Community meetings on Cultural Heritage Tourism The focus groups (see Market Analysis) will be followed by one or more "town hall" meetings, with local community leaders, managers of tourism operations in the district, and district residents. Findings from the Site Design and Market Analyses will be presented at these meetings. The objectives of the meetings are to raise awareness of the benefits of Cultural Heritage Tourism, obtain information regarding community perceptions of the tourism industry in the district, determine if there are any areas of concern, seek potential entrepreneurs, identify the project's target areas and ensure the community is involved in decisionmaking in developing and implementing the project.

- Business plan training Potential and existing entrepreneurs will be given the opportunity to attend business plan training seminars. The aim of these seminars is to provide small business owners with the knowledge needed to start and grow a business. The training will include how to write a business plan and find financing. The training will be open to public participation, but limited to 100 participants.

\section{List of potential entrepreneurs}

The project group will identify and recommend ten to twelve candidates and their properties for the next phases of the project (Years Two and Three). The candidates will be identified based on results from the business planning seminars, the site analysis and the building inventory.

\section{Year two}

The deliverables for year two will include architectural drawings, business consultancy, and community training seminars. 


\section{Architectural drawings}

Ten to twelve architectural projects including plans, sections and elevations will be provided to the selected potential entrepreneurs. Drawings will be suitable for submission to the Historic and Design Review Commission (HDRC).

\section{Business consultancy}

Advanced training and consultancy will be given to the ten to twelve selected potential entrepreneurs.

\section{Community training seminars}

Training seminars will be provided to selected business owners and service employees of tourism and hospitality organizations. Potential and existing entrepreneurs will also be given the opportunity to attend the essentials of starting a business seminar (open to public, but limited to 100 participants).

\section{Year three}

The deliverables for the third and final year of this project will include consultancy on implementation of the projects, destination marketing studies, and final report.

By the end of the third year, selected entrepreneurs will be trained on how to run a small business on cultural heritage tourism, financially assisted and supported, and ready to start up their own businesses. They will also be done with the construction and/or renovation of their own properties.

\section{Conclusion}

While 1.7 million people visit the Missions, the impact of those visits has not translated to positive economic development for the local community. Identification of the cultural and historical assets, inventory of the existing landscape and buildings, and determination of the adaptive reuse will emphasize and highlight the real potential of the site. Real opportunities do exists to capitalize on the Missions and the new public investment into the river improvements.

The proposed survey, study and analysis of the proposed project area should encourage the revitalization of the Mission Historic District. The area will regain its sense of identity and share its treasures of history, culture and heritage with all who visit and those who decide to stay.

World Heritage designation of the San Antonio Missions will bring international attention to the district. The Harbinger Consulting Group [6] states, "Cultural travelers, whether domestic or international, look for experiences that are unique to a place. The World Heritage Site can be used to capture the attention of these potential visitors, but they will be looking for other high quality, engaging, authentic cultural experiences to augment their WHS visit. Use WHS designation as a catalyst for developing and connecting other heritage tourism opportunities and local businesses.” In this respect, this project proposal 
is very important and timely in order to support and connect community small business owners to the existing heritage tourism economy. Finally the success of projects completed will encourage other local business entrepreneurs on their initiatives. It is expected that successful local business in the area will cause a ripple effect, and create prosperity for the residents in the area while sustaining the community's cultural heritage.

\section{Acknowledgements}

I would like to thank UTSA Center for Cultural Sustainability, William Dupont, Claudia Guerra, and David Bojanic for their support and collaboration on this project proposal.

\section{References}

[1] Kester, J.G.C., 2012. 2011 International Tourism Results and Prospects for 2012, UNWTO News Conference, HQ, Madrid, Spain, 16 January 2012. http://dtxtq4w60xqpw.cloudfront.net/sites/all/files/pdf/unwto_hq_fitur12_jk 2pp_0.pdf (accessed 03/03/2012).

[2] UTSA Institute for Economic Development's Center for Community and Business Research in conjunction with The Harbinger Consulting Group, 2011. Economic Impact of the San Antonio Missions, National Historic Parks, http://ccs.utsa.edu/pdf/EconomicImpactMissions.pdf (accessed 03/03/2012).

[3] National Trust for Historic Preservation, Heritage Tourism, http://www.preservationnation.org/information-center/economics-ofrevitalization/heritage-tourism/\#.UTO_fTk 644 (accessed 03/03/2012).

[4] Lyon, S.M. and Wells, E.C., 2012. "Ethnographies of Global Tourism: Cultural Heritage, Economic Encounters, and the Redefinition of Impact”, Global Tourism: Cultural Heritage and Economic Encounters, AltaMira Press, UK, pp. 1-21.

[5] Lefebvre, Henri. 1974. The Production of Space, Wiley-Blackwell, London, UK.

[6] The Harbinger Consulting Group, 2013. Building on a Strong Foundation: Potential Economic Impact of World Heritage Site Designation for the San Antonio Missions, http://www.bexar.org/whs/Missions_WHS_Report.PDF (accessed 03/03/2012).

[7] City of San Antonio, Office of Historic Preservation, Local Historic Districts, Mission, http://www.sanantonio.gov/historic/Districts/Mission. aspx (accessed 03/03/2012).

[8] UNESCO World Heritage Centre, Tentative List: San Antonio Franciscan Missions, http://whc.unesco.org/en/tentativelists/5247/ (accessed 03/03/ 2012).

[9] San Antonio River South Area Coordinated Management Plan, ProtectPromote-Coordinate, 2010. http://www.sanantonioriver.org/images/River South_Management_plan_12_08_2010.pdf (accessed 03/03/2012). 